\title{
Population estimation and biology of hooded crow (corvus corone cornix) at ismailia governorate.
}

\author{
Mostafa, M. A. *; M. M. D. Khattab**; M. A. M. El-Danasory* and M.A. I. Attia** \\ * Agric. Zoology \& Nematology Department Fac. Agric., Al-Azhar Univ. \\ ** Plant Protection Institute, Agriculture Research Center. Dokki, Giza, Egypt.
}

\begin{abstract}
This study investigated the ecology of the hooded crow Corvus corone cornix (Passeriformes: Corvidae) at Ismailia Governorate. The highest population density of hooded crow Corvus corone cornix recorded at sunrise were 11.67 and 10.33 individuals during July and September 2007 in fields cultivated with vegetables and field crops respectively. While at sun-set the highest population recorded 6.33 and 5 individuals during January 2009 and August 2007 in fields cultivated with vegetables and field crops respectively. The breeding season of hooded crow had been lasted from January to April. The mean number of eggs per clutch differs from 3.25 to 5.5 eggs per clutch with mean 4.07 eggs/clutch. The total mean of incubation period was 18.57 days while the total mean of the fledging period was 31.23 days. The total survival rate was $84.08 \%$.
\end{abstract}

Keywords: Ecology, Biology, Corvus corone cornix, Field and vegetable crops

\section{Introduction}

In Egypt the hooded crow (Corvus corone cornix) was common resident in all habitats, cultivated parts of the Nile Delta and valley (South to Aswan) and along the Suez canals area including Portsaid and Suez it's an omnivorous bird and is a constant scavenger (Mullié and Meininger 1985; Goodman et. al 1989; EL-Danasory 2002; Cocker et al., 2005). The hooded Crow (Corvus cornix) differ significantly in the year months with highly abundance and distribution during the breeding season which reached its peak at february, also average was declined at the non-breeding season months (Bonnah 2007; Khattab 2002).

The aim of this work is to spot more light upon the population fluctuations, daily activities, clutch size, incubation period, hatchability, and fledging period and survived of hooded crow at Ismailia Governorate in Egypt.

\section{Materials and Methods}

The hooded crow Corvus corone cornix an Ashley grey bird with black head, throat, wings, tail and thigh feathers, as well as a black bill, eyes and feet. It is omnivorous, and is a constant scavenger.

\section{Population fluctuations and daily activities of hooded crow Corvus corone cornix:}

Population fluctuations of hooded crow Corvus corone cornix were studied monthly daytime (sunrise and sunset) at two different habitat (field crops \& vegetables crops) from April 2007 to March 2009 in three district (Eltal Elk-beer, Fayed and EL-Qantara) at Ismailia Governorate to find the distribution of birds at different year seasons. Bird activity was expressed by counting individuals for one hour during different intervals i.e. before sun-rise and before sunset. The population counts were carried out by the field glass binocular, in the three districts mentioned above. Data were analyzed according to multiply range test Duncans (1955).

\section{Some biological aspects associated with hooded crow Corvus corone cornix:}

A biological study on hooded crow conducted under the field conditions of Ismailia Governorate during 2010. All nests classified into two categories, the first one on tree near by water canals; while the second on tree nearby buildings. Nests were checked during the early morning, in order to reduce disturbance during incubation and avoid exposing of the eggs to excessive solar radiation.

Known numbers of nests were chosen to determine the clutch size, incubation period, hatchability, fledging period and survival.

Clutch size is the number of eggs laid in a single nest. Incubation period was defined as the time elapsed between the last egg laying and hatching of it according to Swanberg (1959). Hatchability was defined as the ratio of the number of nestlings hatched to the number of eggs laid (Zduniak and Kuczynski 2003). The time between the day of the first egg hatching and the day which the bird possess true feather and able to leave the nest represent the fledging period. The number of fledging defined as the number of nestling represent in the nest during the last visit (Kosicki, 2011). The term breeding success refers to the probability of rearing at least one fledging. Proportion of surviving was defined as number of fledged birds to the number of hatching eggs.

\section{Results and discussion}

1. Population fluctuations and daily activities of hooded crow Corvus corone cornix: 
Data in fig (1) illustrated that, the highest population were recorded at sun-rise 11.67 and 10.33 individuals during July and September 2007 in fields cultivated with vegetables and field crops respectively, While at sun-set the highest population recorded 6.33 and 5 individuals during January 2009 and August 2007 in fields cultivated with vegetables and field crops respectively. On the other hand the lowest populations at sun-rise were 4 and 0.67 individuals during March 2008 and July 2008 in fields cultivated with vegetable and field crops respectively, while it absent during March 2008 in fields cultivated with vegetables at sun-set and in fields cultivated with crops during May 2007, August and November 2008.
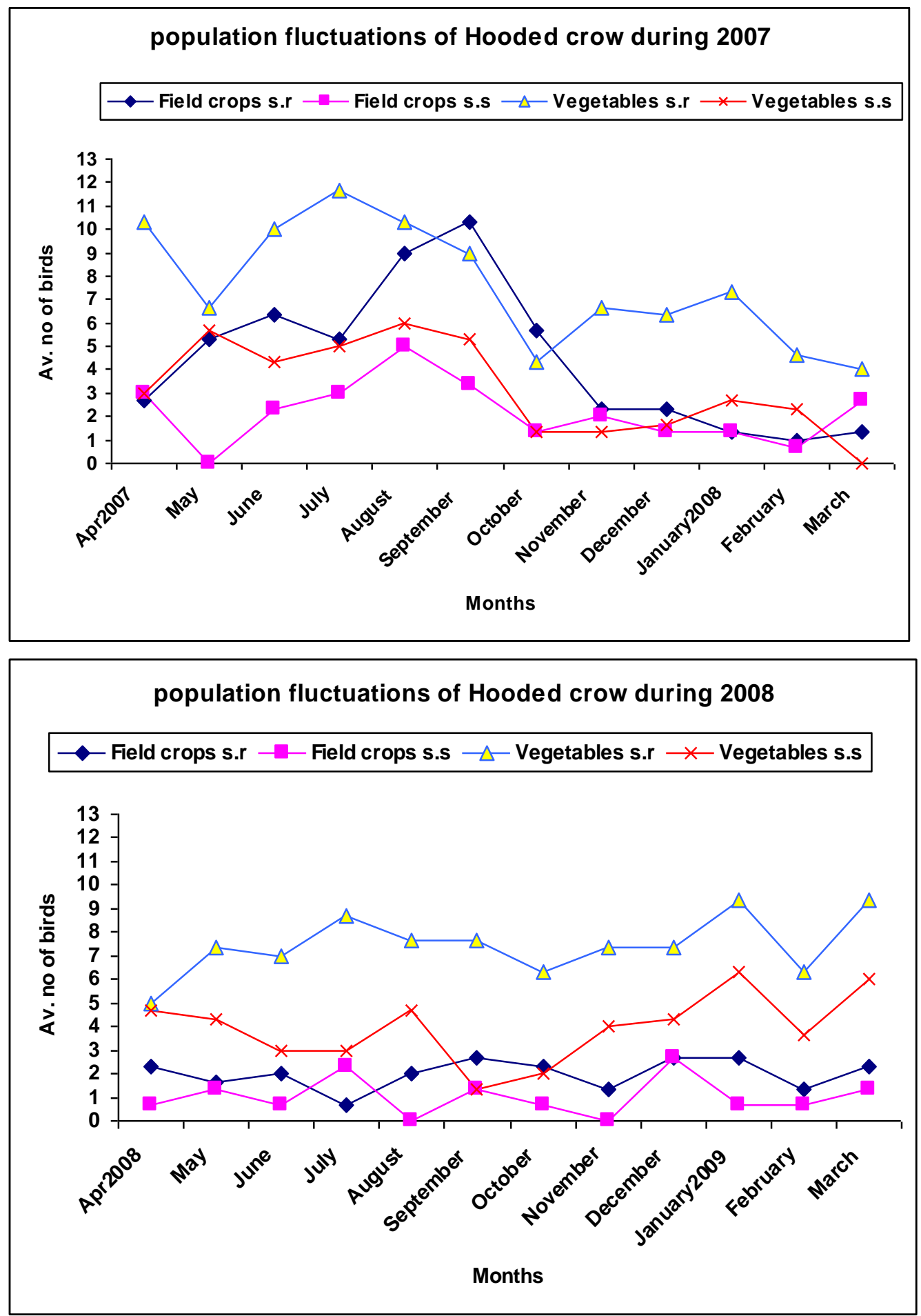

Fig. (1) Monthly population fluctuations and daily activities of hooded crow Corvus corone corenix in different crops at Ismailia Governorate from April 2007 to March 2009.

$$
\text { s.r. }=\text { sun rise } \quad \text { s.s. }=\text { sun set }
$$


Statistical analysis of data indicated that, there was no significant difference between the months of study (April 2007 to March 2009), at the different location. On the other side, there was significant difference between population densities of this bird under the different location (field crops and vegetables) in the first year and the second year. On the same trend there was highly significant variance between population density of this bird under day time (sun-rise and sunset) with high populations during sun-rise than sun-set in both year with population $6.01,4.72$ individuals and 2.69, 2.49 individuals respectively.

our results agree with these recorded by ElDanasory (2006) he cleared that; the highest number of hooded crow recorded during sun-rise near buildings and trees in May, followed by near orchards, field crops and water canals in August, May and July 2003 respectively. While during sunset the highest number of hooded crow recorded near orchards in July followed by near building then field crops and water canals in May and July respectively. Bonnah (2007) revealed that, the number of hooded crow increased annually during spring followed by autumn and decreased during summer and winter. Also Hassan (2008) revealed that, hooded crow Corvus corone cornix numbers was differed according the study area, Qalubia governorate showed highest population from March to August and lowest number during October, while the highest at Sharkia Governorate during July and the lowest in Novermber. At Ismailia Governorate two peaks were recorded during June \& November, while the lowest during February \& October. Also she cleared that the population of hooded crow was higher during summer season.

\section{2-1 Number of clutches and eggs:}

The term clutch of eggs refers to all the eggs produced by Bird often at a single time, particularly those laid in a nest of birds. clutch size differs greatly between species, sometimes even within the same genus; it may also differ within the same species due to many factors including habitat, health, nutrition, predation pressures, and time of year (Lack 1947). Average clutch sizes range from one a sin condor to about 17 the Grey partridge.

The data in fig (2) cleared that under the conditions of the different habitats (Near water canals and near building), hooded crow laid one clutches. The breeding season had been started from January to April. The number of clutches record the highest population on trees nearby building in March with 7 clutches and 6 clutches on trees near by water canals at the same month. While the lowest population recorded in January on trees adjacent to the two habitats with 2 clutches in both.

The mean numbers of eggs per clutch differ from 3.25 to 5.5 eggs per clutch with mean 4.07 eggs/clutch, the highest numbers of eggs laid on the tree near water canals were in February with 5 eggs/clutch and the lowest were in April with 3.33 eggs/clutch. On the other hand the highest numbers of eggs laid on the tree near by building were in January with 5.5 eggs/clutch and the lowest were in February with 3.25 eggs/clutch. The total numbers of inspected eggs were 116eggs.

\subsection{Incubation period:}

Incubation period of an egg is the time from the start of regular un interrupted incubation to hatching. Incubation period of hooded crow Corvus corone cornix differed according to temperature increased, the mean of incubation period for all inspected nest was 18.57 days. The incubation period on the trees near water canals recorded 19.5, 18.67, 18.33 and 18.33 day during January, February, March and April respectively. On the other hand on the trees near by building the incubation period recorded 19, 18.5, 18.28 and 18 at the same months respectively. Nests were cheeked once every two days during the laying period and each egg was individually marked (Erez and Yom-Tov 1995). The field work was carried out daily during the breeding season of 2010 (Soliman1999, Samraoui et al. 2007).

\subsection{Hatchability:}

The hatchability for the clutches on the trees near by water canals give the higher population $80 \%$ in April following by January with $75 \%$ then February with $73.33 \%$ while the lowest in March $66.66 \%$. On the other hand the hatchability for clutches on the trees near by building recorded the highest population during February with $92.30 \%$ then March with $78.57 \%$ and the lowest in January with population $63.63 \%$. The overall hatchability recorded $75.11 \%$

\subsection{Fledging period and survival:}

The fledging period recorded the highest population during January with 33.5 and 32.5 day for clutches (on tree near water canals and on tree near building respectively) while the lowest during April with 29.67 and 29.5 day respectively, May be that because the lack of a food source during the different months. The total mean of the fledging period was 31.23 days.

The total survival rate was $84.08 \%$, and ranged from $72.72 \%$ to $93.75 \%$. The highest population recorded during March with $93.75 \%$ and $86.36 \%$ on tree near canals \& drains and on tree near building respectively.

The results confirmed by Zduniak and Antczak (2003) the mean clutch size was 4.43 eggs and ranged from 2 to 9 eggs. Bonnah (2007) reported that the most breeding season was found during spring months than autumn months, the number of egg per nest differ from 3.9 eggs/nest to $1.9 \mathrm{egg} / \mathrm{nest}$. 

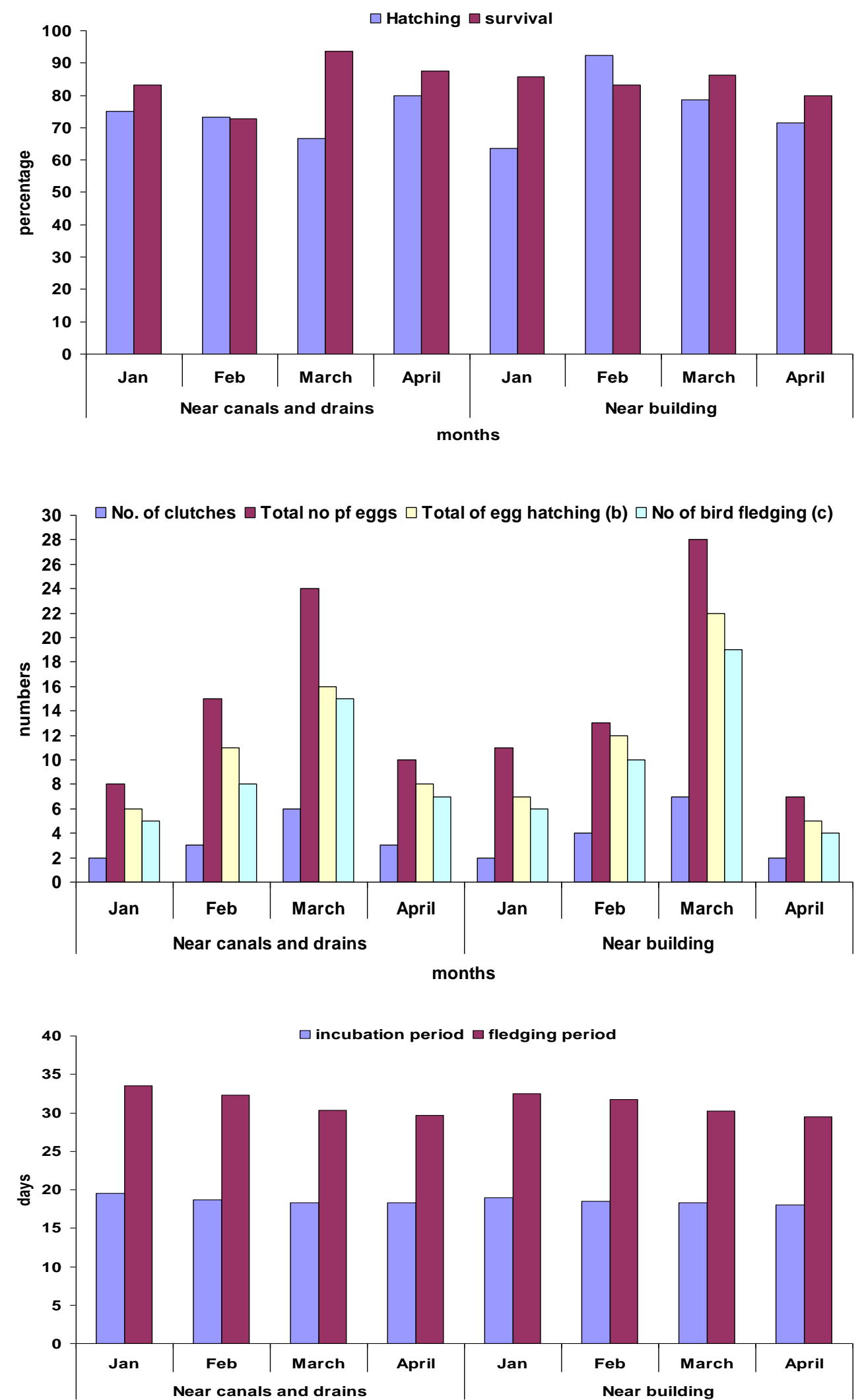

Fig. (2) Some biological aspects of Hooded crow Corvus corone cornix at Ismailia Governorate. 
Habib (2008) revealed that egg lying of house crow started in June and most of clutches were completed by the end of July, mean clutch size was 4.1 eggs and ranged from 1 to 7 eggs. Behrouzi-rad (2010) cleared that house crow has a single breeding season from late May to early September. Ranjan and Kushwaha (2013) stated that mean clutch size of house crow 4.4 eggs and ranged from 4-5 eggs. Shobrak (2005) revealed that incubation period for house crow in Saudi Arabia varied from 20-23 days. Habib (2008) mentioned that house crow took 15-17 days to incubate eggs.

In contrast, the obtained results of Zduniak \& Kuczynski (2003) cleared that overall Hatchability $76 \%$ and was not different among breeding season. Shobrak (2005) revealed that overall hatchability of house crow $33.3 \%$. The effect of weather on nestling survival differs among bird species (Cotton 2003).

Zduniak (2010) Stated that the environmental factors can significantly reduce reproduction success by causing low chick survival. Kosicki (2011) revealed that there was a positive correlation between white stork nestling survival and weather condition, the mean survival rate of the whole nesting of white stork was $90 \%$.

\section{References}

Behrouzi-Rad, B. (2010). Population estimation and breeding biology of the house crow Corvus splendens on Kharg Island, Persian Gulf. Podoces, 5(2): 87-94.

Bonnah, A. A. M. M. (2007). The damage by and control of hooded crow on some plantation in Sohag Governorate. Ph.D. Thesis, faculty of Agriculture, Assiut University, Egypt, 116 pp.

Cocker, M.; Mabey, R. (2005). Birds Britannica. London: Chatto \& Windus. pp. 418 - 425. ISBN 0-7011-6907-9.

Coton P. A. (2003). Avian migration phenology and global climate change, proceedings of the National Academy of sciences of the USA 100: 12219-12222.

Duncan, D. B. (1955). Multiple range and multiple F-test. Biometrics, 11: 1-41.

El - Danasory, M. A. (2002). Ecological and biological studies on some harmful birds for plants at Minoufia Governorate. M. Sc. Thesis, Fac. of Agric., Al-Azhar Univ.

El - Danasory, M. A. (2006). Studies on some wild bird species in Egypt. Ph. D. Thesis Faculty of Agric. Al-Azhar Univ.

Erez, A. and Y. Yom-Tov, (1995). Reproduction of A hooded crow Corvus corone population in Israel. Ardea 83:405-409.

Goodman, S.M.; Meininger, P.L.; Bahaa El-Dine Sh. M.; Hoobs, J.J. and Mullie, W.C. (1989) The birds of Egypt. Univ. Oxf., New York.

Habib A. (2008). Behavior and ecology of the house crow Corvus splendens in Islamabad-Rawalpindi and Adjoining Area. Ph.D. Theses in Zoology, University of Agriculture Faisalabad.

Hassan, E. Kh. K. (2008). Enveronmental problems in relation to Corvidae birds and their management in west and east Delta. M.Sc. Thesis, Inst. Of Enviro. Studies and Res. Ain Shams Univ.

Khattab, M. M. (2002). Field study on population fluctuation of hooded crow, Corvus corone saronius (KleinSchmidt), At Sharkia Governorate. 2nd International Conference, Plant protection Research Institute, Cairo, Egypt.21-24December2002.PP.115-120.

Kosicki, J. Z. (2011). Effect of weather conditions on nestling survival in the white stork Ciconia ciconia population. Ethology Ecology \& Evolution, vol 24 (2): 140-143.

Lack, D. (1947). The significance of clutch size (part 1-11) Ibis 89:302-352.

Mullie, W.C. and Meininger, P.L. (1985) The decline of bird of prey population in Egypt. ICBP Tech. Publ., No. S., 61-82.

Ranjan, G. and P. K. Kushwaha (2013). Study on breeding ecology of Corvus splendens, Acridotheres tristis and Psittacula krameri in Parsa district, Nepal. Proc. Natl. Acad. Sci., India, sect. B Biol. Sci. 83(1) : 27-30.

Samraui, F.; R. Menai and B. Samraoui (2007). Reproductive ecology of the cattle egret (Bubulcus ibis) at sidi Achour, North Eastern Algeria. Ostrich, 78(2): 481-487.

Shobrak, M. (2005). Breeding success of brownnecked raven Corvus ruficollis in the Mahazat as-Sayd Protected Area, Saudi Arabia. Sandgrouse 27 (2):152-156.

Soliman, A. M. A. (1999). Eco- Biological studies on some wild bird species at Kafr El-Sheikh Governorate with species reference to some Arthropods. Ph.D. thesis. Fac. Agric., Zagazig Univ.

Swanberg, P. O. (1959). On the concept of incubation period var. Fogel . 9: 63-80.

Zduniak, P. And M. Antczak (2003). Repeatability and within clutch variation in egg dimensions in a hooded crow Corvus corone cornix population. Biol. Lett, 40(1) : 37-42.

Zduniak, P. and L. Kuczynski (2003). Breeding biology of the hooded crow Corvus corone cornixin warta river valley(WPoland). Actaornitholoica 38:143-150.

Zduniak, P. (2010). Water conditions influence nestlings survival in a hooded crow Corvus cornix wetland Population. Journal of ornithology 151: 45-50. 


\section{تقدير الكثافة العددية ودراسات إحيائية لطائر الغراب البلاى فى محافظة الاسماعيلية}

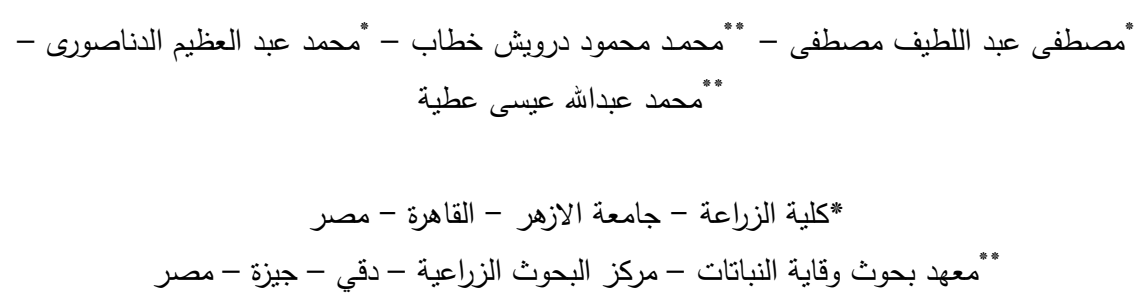

اشتملت هذه الدراسة علي الدراسات الايكولوجية للغراب البلدي(رتبة العصفوريات - جنس الغراب) في محافظة الاسماعيلية. سجلت أعلى كثافة تعداد للغراب البلدي Corvus corone cornix عند الثروق 1.67 و 10.33 فرد خلاد شهري يولية وسبتمبر 2007 في الحقول المزروعة بمحاصيل الخضر والحقول المنزرعة بالمحاصيل الحقلية علي التوالي. بينما سجل أعلى تعداد عند الغروب 6.33 و 5.00 افراد خلا شهر يناير 2009م وشهر اغسطس 2007م لكلا من الحقول المزروعة بمحاصيل الخضر والحقول المنزرعة بالمحاصيل الحقلية علي النوالي. يمتد موسم التكاثر للغراب البلدي من شهر يناير وحتي شـهر ابريل. ومتوسط عدد البيض لكل حضنة من 3.25 الي 5.5 بيضـة لكل

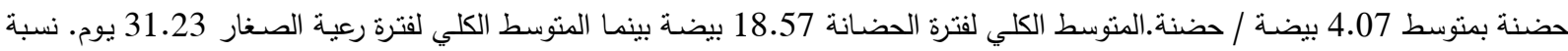
البقاءالكلية 84.08\% ( 208. 